(c) American Dairy Science Association, 2005.

\title{
Automatic Milking and Grazing-Effects of Location of Drinking Water on Water Intake, Milk Yield, and Cow Behavior
}

\author{
E. Spörndly and E. Wredle \\ Swedish University of Agricultural Sciences (SLU), Department of Animal Nutrition and Management, \\ Kungsängen Research Center, SE-753 23 Uppsala, Sweden
}

\begin{abstract}
In an automatic milking system with cows grazing on a mixed grass sward, experiments were performed in 2001 and 2003, lasting 10 and 7 wk, respectively. Two location strategies for offering drinking water were compared: available in the barn and in the field (group $\mathrm{B}+\mathrm{F}$ ) or only in the barn (group B). During 2001, cows grazed alternately at 2 pastures at different distances from the barn, $50 \mathrm{~m}$ (near pasture) or $330 \mathrm{~m}$ (distant pasture), whereas the distant pasture was mainly used in 2003. No significant differences in milk yield, milking frequency, or milk composition were found between the 2 treatments. Average milk yield in the 2 experiments was 26.8 and $27.6 \mathrm{~kg}$ of milk in 2001 and 2003 , respectively, and average milking frequency was 2.4 milkings/ d. Significant differences in animal behavior were observed only during the period when animals grazed on the distant pasture in 2001, with animals in group $\mathrm{B}+\mathrm{F}$ spending $40 \%$ of their time on pasture and $21 \%$ of their time grazing, whereas corresponding values for group B were 34 and $17 \%$, respectively. In 2003, average drinking water intakes per cow were $53 \mathrm{~L} / \mathrm{d}$ on treatment $\mathrm{B}$ and $51 \mathrm{~L} / \mathrm{d}$ on treatment $\mathrm{B}+\mathrm{F}$, and were not significantly different. Total daily water intake including water in the pasture was approximately $90 \mathrm{~L} / \mathrm{cow}$. In conclusion, no significant differences in milk yield, milking frequency, or water intake were found between cows offered drinking water both in the barn and in the field compared with drinking water only in the barn at pasture distances up to $330 \mathrm{~m}$.
\end{abstract}

(Key words: automatic milking, grazing, water supply, milk production)

Abbreviation key: AMS = automatic milking system, $\mathbf{B}=$ drinking water in barn, $\mathbf{B}+\mathbf{F}=$ drinking water available in barn and field, $\mathbf{D P}=$ distant pasture $(\sim 330$ $\mathrm{m}$ from barn $), \mathbf{N P}=$ near pasture $(\sim 50 \mathrm{~m}$ from barn $)$.

Received September 10, 2004.

Accepted February 4, 2005.

Corresponding author: Eva Spörndly; e-mail: Eva.Sporndly@ huv.slu.se.

\section{INTRODUCTION}

With the introduction of automatic milking systems (AMS), a new concept for dairy production was introduced, and production and management routines need to be changed and adapted to the new system. One of the differences between conventional and robotic milking systems is that the cows with AMS are no longer herded from the field to the barn during the grazing season. Instead, they are expected to go voluntarily to the milking unit several times daily to be milked. Surveys and on-farm studies have shown that the milking frequency drops to some extent when cows are turned out to pasture. In a survey involving 25 farms with automatic milking and grazing, the average number of milkings was 0.2 milkings/cow per d lower in the summer (i.e., when grazing) than in the winter (van Dooren et al., 2002). Spörndly and Wredle (2002) also reported lower milking frequency during the grazing season compared with the indoor season. Therefore, farmers with AMS often make drinking water available in the barn only to stimulate the animals to return from the pasture to be milked. In a survey performed in 2001 with 116 farmers using AMS in the Netherlands, the majority practiced some type of grazing; 53\% offered grazing (strip, rotational, continuous, or other) and 6\% offered mainly exercise with only 1 paddock smaller than 1 ha (van Dooren et al., 2002). Of the 68 farms where the animals were outdoors during the summer, $41 \%$ offered the cows drinking water only in the barn. The practice of offering water only in the barn has also been reported in farm studies performed in Denmark (Krohn and Munksgaard, 2004) and Sweden (van Dooren et al., 2002).

Concerns could be raised that supplying water only indoors may limit the cows' intake of water and have a negative effect on milk production. The National Research Council (NRC, 2001) concluded that production could be rapidly and severely depressed if water availability was limited. In an extensive review on water metabolism published by Murphy (1992), the need to provide ample water to maximize milk production is emphasized. However, it is difficult to say whether offering water only in the barn is limiting water availabil- 
ity because automatically milked cows are free to return to the barn to drink at any time. Conversely, it may be argued that animals offered water in the field as well as in the barn might not come sufficiently often to the milking unit to maintain a high level of milk production, which might lead to low milking frequencies, lowered milk production, and an increased need for them to be fetched for milking. The objective of this experiment was to study the effects of 2 watering strategies for automatically milked cows on 24-h grazing regimens; water offered only in the barn, and water offered both in the barn and in pasture. The effects on milk yield, milk composition, milking frequency, number of times cows needed to be manually fetched for milking, intake of supplements, and cow behavior were evaluated in both 2001 and 2003. In 2003, the effect of treatment on water intake of cows was also studied.

\section{MATERIALS AND METHODS}

\section{Animals and Barn Layout}

Of the $\sim 50$ Swedish Red and White breed cows that were housed and milked in the barn, 39 cows were included in the statistical analyses for 2001, and 46 were included for 2003. The cows were of 2 genetic selection lines (described by Åkerlind et al., 1999) and were mainly in mid or late lactation with an average of 191 DIM in both 2001 and 2003 (range 14 to 374 DIM). Animals were weighed, and milk yield, milk composition, and water intake (in 2003 only) of each experimental animal was measured during the last $2 \mathrm{wk}$ before the start of the pasture period. Average milk yield was 30.3 and $29.0 \mathrm{~kg}$ of milk/cow per d, and average live weight of cows was 603 and $632 \mathrm{~kg}$ in 2001 and 2003 , respectively, at the initiation of the experiments when animals were turned out onto pasture. The proportions of primiparous cows were 21 and $28 \%$ in 2001 and 2003 , respectively.

In 2001 , cows were blocked by parity (primiparous and multiparous cows) and randomly assigned to 1 of 2 treatment groups. In 2003, groups of 4 animals with similar milk yield and water intake before the experiment were blocked together. Animals in these blocks were then randomly assigned to the 2 treatment groups.

The experiments were performed using a DeLaval Voluntary Milking System (VMS, De Laval, Tumba, Sweden). The barn layout is presented in Figure 1. The barn consisted of a resting area with 54 cubicles (freestalls), 2 identical feeding areas, and 1 milking unit with a collection area. Each feeding area had 10 separate feed troughs for roughage feeding and 1 concentrate feeder.

Animals in the resting area needed to pass the selection gates to enter the feeding area. Cows with milking access ( $>7 \mathrm{~h}$ after the previous milking) had to pass the milking unit on the way to the feeding area. An exit gate from each feeding area led to a cow track where cows could choose to continue out to pasture or to reenter the barn via the entrance gate. Cows with milking access that entered the barn could not leave the barn and return to pasture without passing the milking unit to be milked.

Milking access was granted $7 \mathrm{~h}$ after the previous milking. At approximately 0500 and $1700 \mathrm{~h}$, cows that had not been milked during the last 12 to $14 \mathrm{~h}$ were fetched to be milked.

\section{Treatments and Management}

The treatment groups differed with regard to drinking water location. Animals in treatment group Barn (B) were offered drinking water in the barn only, whereas those in treatment group Barn and Field $(\mathbf{B}+\mathbf{F})$ were offered drinking water in the barn and out in the field.

After milking, animals in the 2 treatment groups were directed to separate feeding areas via an automatic gate. From the exit gate of each feeding area, cow lanes and 1-way gates led the animals to separate paddocks. Cows returning to the barn were directed by 1-way gates in the cow track and entered the barn through the same entrance gate. Two main pasture areas were used; the distant pasture (DP, $\sim 330 \mathrm{~m}$ from barn) and the near pasture (NP, $\sim 50 \mathrm{~m}$ from barn), each divided into 2 paddocks to enable the 2 treatment groups to graze at the same distance at the same time. In Figure 2, the position of the barn in relation to the $\mathrm{NP}$ and DP and the paddocks used by treatment groups $\mathrm{B}$ and $\mathrm{B}+\mathrm{F}$ are shown.

Animals were set stocked, returning to the same pasture area each day. When pasture became scarce on $\mathrm{DP}$, the animals were switched over to the NP area. The DP could not be seen from the area near the barn. The paddocks on the DP were 3 ha each and approximately $350 \mathrm{~m}$ from the barn exit with the farthest point of pasture approximately $650 \mathrm{~m}$ away. The corresponding distances for the 2-ha NP paddocks were 50 and 300 $\mathrm{m}$. The pastures were mixed grass swards dominated by Kentucky bluegrass (Poa pratensis) and meadow fescue (Festuca pratensis).

Grass silage was offered as a supplement to all cows in 2001 ( $\sim 3 \mathrm{~kg}$ of $\mathrm{DM} / \mathrm{d})$, whereas in 2003 , cows were divided into 2 feed groups and only cows in the first part of their lactation $(<140$ DIM) received a silage supplement ( $\sim 7 \mathrm{~kg}$ of $\mathrm{DM} / \mathrm{d})$. Besides grass silage, in both years, animals in all treatment groups were offered $1 \mathrm{~kg}$ of hay/d plus concentrates. The animals received a small amount of concentrate in the milking 


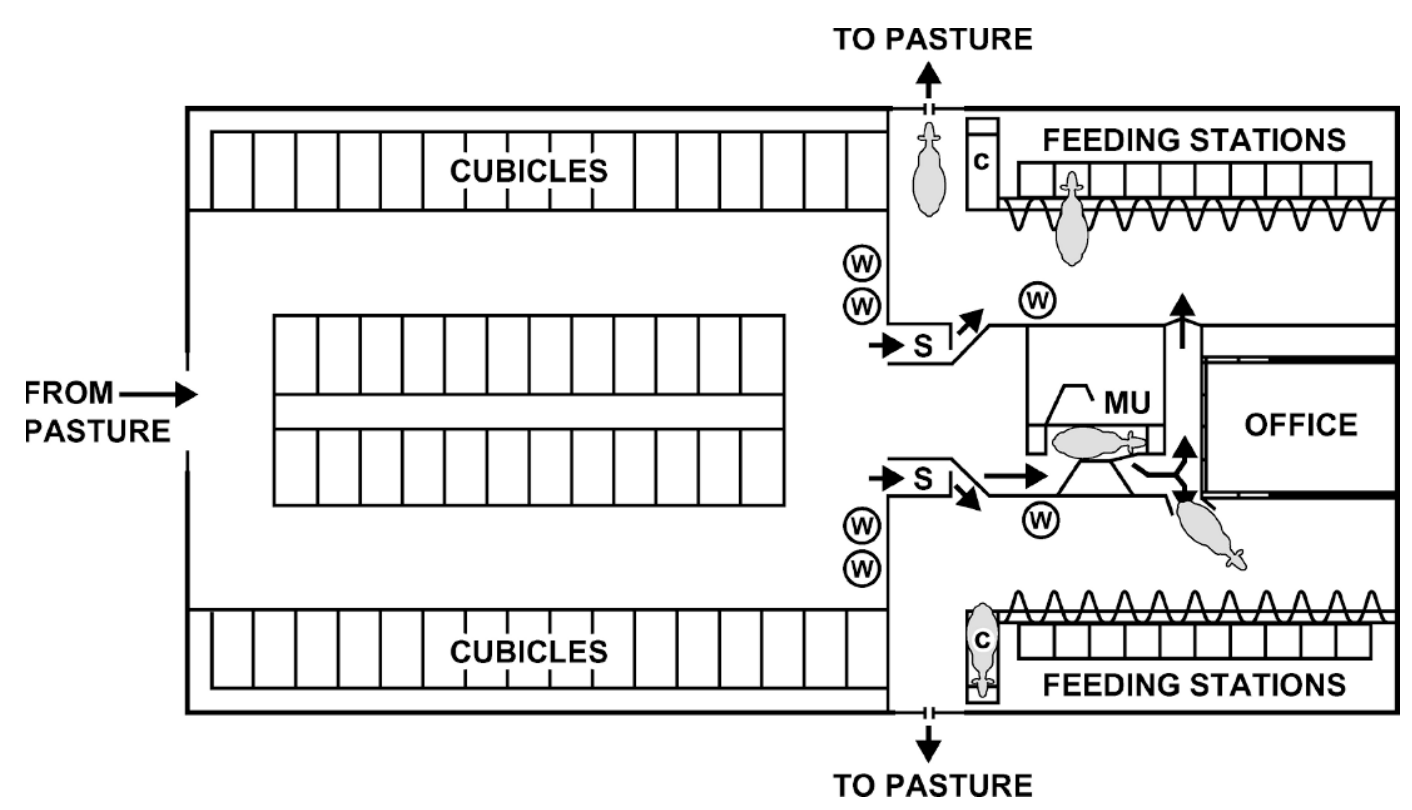

Figure 1. Barn layout. Resting area with 54 cubicles (freestalls), 2 feeding areas, each with 10 roughage feeders and 1 concentrate feeder (c), selection gates (S) that allow passage to the feeding area for cows that are not due for milking, water bowls (w), and milking unit (MU) with a milking robot for automatic milking.

unit $(0.5 \mathrm{~kg})$, and the rest of the concentrate ration was supplied in the concentrate feeders. Each cow was offered concentrate according to milk yield immediately before being let out onto pasture. The concentrate allowance for cows in early lactation with a production above
$35 \mathrm{~kg}$ of energy-corrected milk was based on the assumption of an intake of $110 \mathrm{MJ}$ of metabolizable energy or approximately $10 \mathrm{~kg}$ of DMI from roughage (pasture, supplemental hay, and silage). For cows at lower production levels, an intake of $130 \mathrm{MJ}$ or $12 \mathrm{~kg}$

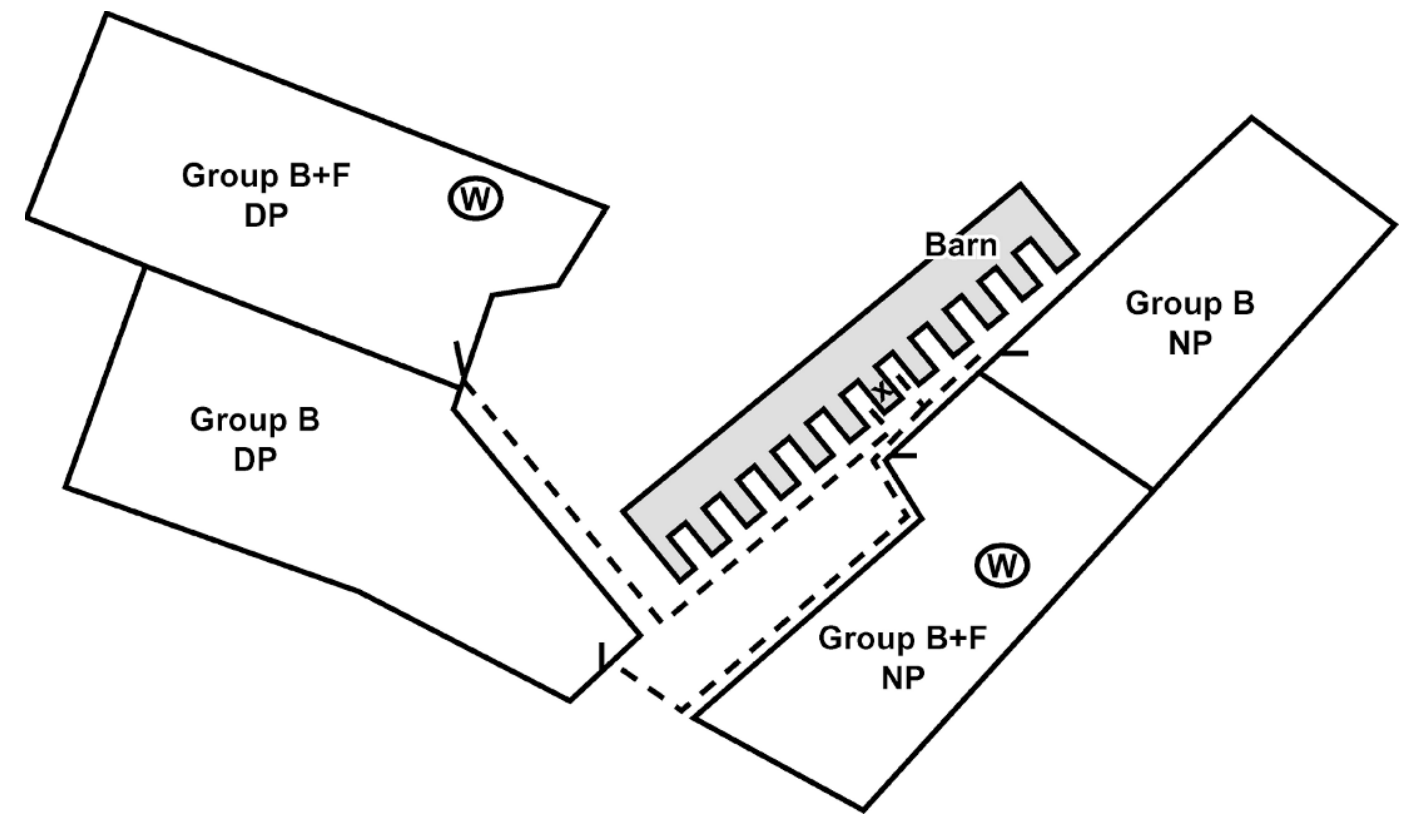

Figure 2. Layout of barn and position of near (NP, $\sim 50 \mathrm{~m}$ from barn) and distant (DP, $\sim 330 \mathrm{~m}$ from barn) pastures. Automatic milking barn, water bowls (W), cow lanes (--), and paddocks for cows with water only in the barn (group B) and for cows with water in the barn and in the pasture (group $\mathrm{B}+\mathrm{F}$ ). 
Table 1. Grazing periods and data collection periods in the experiments.

\begin{tabular}{llll}
\hline Period & & 2001 & 2003 \\
\hline Covariate & Data collection & May 1 to 15 & May 1 to 15 \\
Transition & Grazing & May 16 to June 9 & May 16 to 30 \\
& Data collection & - & May 24 to $30^{1}$ \\
Distant pasture & Grazing & June 10 to July 8 & May 31 to June 23 \\
& Data collection & June 16 to July $8^{2}$ & May 31 to June $23^{3}$ \\
Near pasture & Grazing & July 9 to 23 & June 24 to July 2 \\
& Data collection & July 10 to 23 & June 26 to July $2^{3}$ \\
\hline
\end{tabular}

${ }^{1}$ Behavior and water intake only.

${ }^{2}$ June 29 to 30 was excluded due to technical problems.

${ }^{3}$ Behavior and water intake data for periods on distant (330 $\mathrm{m}$ from barn) and near (50 $\mathrm{m}$ from barn) pastures were analyzed separately, whereas milk production and feed intake data from the periods were pooled for the statistical analysis.

of DMI from roughage was assumed. The concentrate allowance was kept the same throughout the experiment.

Roughage feeding and concentrate allowance were controlled on an individual cow level. Roughage troughs and concentrate feeders were programmed and once a cow had consumed its daily ration, the troughs or feeders were closed to further consumption for that particular cow. Daily roughage and concentrate allowances were divided into 4 portions spread over 6 -h periods each day, preventing the cow from eating all its supplements at once. Feed allowance that had not been consumed during one 6 -h period could be consumed in the following period. For concentrates, there was a $20 \%$ carryover of unconsumed allowance from one day to the next. Concentrate ingredients and composition were as follows: cereal components including barley and oats (50\%); protein feeds including soybean meal and rapeseed products (35\%); and sugar beet pulp (15\%).

\section{Experimental Periods, Registration of Data, Sampling, and Chemical Analyses}

The experiments took place between May 16 and July 23 in 2001, and between May 16 and July 2 in 2003. The first weeks of each experiment were used as a transition period allowing the cows to adapt to the pasture and the treatments. Grazing and data collection periods are presented in Table 1.

The milking frequency, amount of milk from each milking, and the amounts of roughage, concentrate, and water consumed by each cow on each feeding or drinking occasion were registered automatically using transponders to identify individual cows. A milking was defined as a visit to the milking unit yielding more than $0.5 \mathrm{~kg}$ of milk. Sampling of milk for analyses of protein, fat, and lactose contents was performed during 24-h periods; on each occasion collecting samples from at least 2 milkings/cow. This was done before the start of the experiment and at the beginning and end of each experimental period. Energy-corrected milk (Sjaunja et al., 1990) was computed from the results of the analysis, and the 3-d average milk yield ( $\mathrm{kg}$ of milk/d) was registered on the days around the sampling occasion. All cows that had to be fetched for milking were registered twice daily, together with the location of the cow (field or barn) when fetched.

Laboratory analyses were carried out on silage pooled during 2 -wk periods, and on hay and concentrates pooled for 4 -wk periods. In the pasture, herbage was sampled weekly in both pasture areas, dried, and pooled over the experimental periods. All samples were analyzed to determine contents of ash and CP (Olsson et al., 1997). Neutral detergent fiber in silage, hay, and pasture herbage was analyzed according to Goering and Van Soest (1970). Herbage and silage contents of metabolizable energy were determined by in vitro digestion as described by Lindgren (1979). In 2003, sward height was measured and herbage mass was estimated using a regression based on data from the same pasture area (Spörndly and Burstedt, 1996).

\section{Water Intake}

Water intake was registered indoors and outdoors in the 2003 experiment. Before the initiation of the experiment, water bowls (volume $3.3 \mathrm{~L}$ ) were controlled and calibrated (as needed) to ensure correct registration of the cows' water consumption. Flow rates in water bowls in the field and in the barn were 6 and $7 \mathrm{~L} / \mathrm{min}$, respectively. Cows had access to 5 water bowls in the barn, 4 in the section with resting cubicles before passing the milking unit, and 1 water bowl in each of the 2 feeding areas, i.e., 1 for each group after the milking unit (Figure 1). Water intake in the barn was registered automatically through identification of the cow's transponder at the water bowls. 
Water intake of group $\mathrm{B}+\mathrm{F}$ in the field was registered manually during four 48 -h observation periods; once during the transition period, twice when animals grazed on DP, and once when grazing on NP. Group $\mathrm{B}+\mathrm{F}$ had 4 water bowls in the field, which were situated approximately $100 \mathrm{~m}$ from the paddock entrance (Figure 2). Before the experiment, the bowls were calibrated to ensure that water registration was correct under varying conditions $(1,2,3$, or 4 cows drinking at the same time). The water bowls in the field were equipped with meters and each time a cow drank, the cow's number and amount of water consumed was recorded.

Total water intake for each animal was calculated by observing water intake in the barn and outdoors during the same 48 -h period. Water intake from supplements was computed for each cow from the intake and DM content of supplements. Intake of water from pasture herbage was estimated assuming a roughage intake of 10 to $12 \mathrm{~kg}$ of DM (grass silage + hay + pasture) as described earlier, and subtracting the actual DMI of silage and hay to obtain an estimate of pasture herbage intake. Water intake from pasture was then calculated using the estimated herbage intake and the average DM content of pasture at the pasture sampling occasions (20\% DM). In this way, an estimate of total water intake for each animal was obtained.

Due to technical problems, individual water intakes were not registered during the experiment in 2001.

\section{Behavior Observations}

Behavior observations in 2001 and 2003 were performed on 20 and 22 cows, respectively, divided equally between the 2 treatment groups. In 2001, 1 of the cows selected for behavior observations had a hoof infection and had to be excluded from the experiment, leaving only 9 cows in treatment group $\mathrm{B}+\mathrm{F}$. Time-sampling observations on the behavior of each cow were recorded every 15 min during 6 -h periods in 2001. A 15 -min time interval was chosen because it was the time needed to find and observe all 20 animals in the behavior group. The observations were evenly distributed over the day and night periods. Twenty-four observation periods were recorded throughout the grazing season. Four 24$\mathrm{h}$ observations were made during grazing on DP and two 24-h observations on NP. In the 2003 experiment, behavior observations were recorded during 4 uninterrupted 48-h periods. The periods corresponded to the transition period, 2 periods on DP, and 1 period on NP. Observations were made at 15 -min intervals for each animal in the field and each cow's lying, grazing, or other behavior activities were recorded.

For each cow and behavior, the number of observations were summarized for the $48 \mathrm{~h}$ in the transition period, the $96-\mathrm{h}$ period on DP, and the 48-h period on $\mathrm{NP}$, and divided by the total number of observations made on the animal during the same period, thus obtaining the percentage spent on each observed activity during the observation period. In the results, these percentages are referred to as "percentage of time" spent on each activity. The statistical analyses were performed on the percentage values obtained.

\section{Statistical Analyses}

Analyses of variance were performed using the GLM procedure of SAS (SAS Institute, 1989). Milk production and milk composition variables were analyzed using the following models in 2001 and 2003:

$$
\begin{gathered}
\mathrm{Y}_{\mathrm{in}}=\mu+\alpha_{\mathrm{i}}+\beta_{1} \mathrm{~L}_{\mathrm{in}}+\beta_{2} \mathrm{X}_{\mathrm{in}}+\mathrm{e}_{\mathrm{in}}(2001) \\
\mathrm{Y}_{\mathrm{ij}}=\mu+\alpha_{\mathrm{i}}+\gamma_{\mathrm{j}}+\beta_{2} \mathrm{X}_{\mathrm{ij}}+\mathrm{e}_{\mathrm{ij}}(2003)
\end{gathered}
$$

and the following models were used to analyze feed intake data:

$$
\begin{gathered}
\mathrm{Y}_{\mathrm{in}}=\mu+\alpha_{\mathrm{i}}+\beta_{2} \mathrm{X}_{\mathrm{in}}+\mathrm{e}_{\mathrm{in}}(2001) \\
\mathrm{Y}_{\mathrm{ijk}}=\mu+\alpha_{\mathrm{i}}+\gamma_{\mathrm{j}}+\delta_{\mathrm{k}}+\beta_{2} \mathrm{X}_{\mathrm{ijk}}+\mathrm{e}_{\mathrm{ijk}}(2003)
\end{gathered}
$$

where $\mu$ is the overall mean, $\alpha_{\mathrm{i}}$ is the fixed effect of the $i$ th treatment $(i=1,2), \gamma_{\mathrm{j}}$ is the effect of the $j$ th block $(j=1 \ldots 11), \delta_{\mathrm{k}}$ is the fixed effect of the $k$ th feed group $(k=1,2), \beta_{1}$ is the slope of the stage of lactation $\left(\mathrm{L}_{i}\right), \beta_{2}$ is the slope of the covariate $\left(X_{i n}, X_{i j}\right.$, or $\left.X_{i j k}\right)$, and $e_{i n}, e_{i j}$, or $e_{i j k}$ is the random residual effect with $\mathrm{n}$ as the symbol for observations (animals).

The linear effect of lactation stage (DIM) for milk production variables in 2001 was more effective compared with other alternatives (curves or classes). Lactation stage, however, was not significant in the analyses of feed intake and was therefore excluded from the model of feed intake in 2001. In 2003, the effect of feed group was not significant in the analysis of milk production variables but was included in the analysis of the feed intake data. Covariates were obtained from milk composition and milk production data from the last 2 wk before pasture let-out. The variables parity, selection line, and interactions between different variables were tested and found nonsignificant and were therefore excluded from the above models both in 2001 and in 2003. Milk production and feed intake are presented in the results as least squares means together with standard errors.

The large variation among cows in the number of times they needed to be fetched for milking prevents the assumption of normal distribution and therefore 
Table 2. Milk production and milking frequency of cows with drinking water in the barn (group B) or in the barn and in the field (group $\mathrm{B}+\mathrm{F}$ ) when grazing pasture areas distant (DP, $330 \mathrm{~m}$ from barn) and near (NP, $50 \mathrm{~m}$ from barn), in experiments conducted in 2001 and 2003 (least squares means $\pm \mathrm{SE})$. No significant differences $(P>0.05)$ between treatments were found for any of the variables studied.

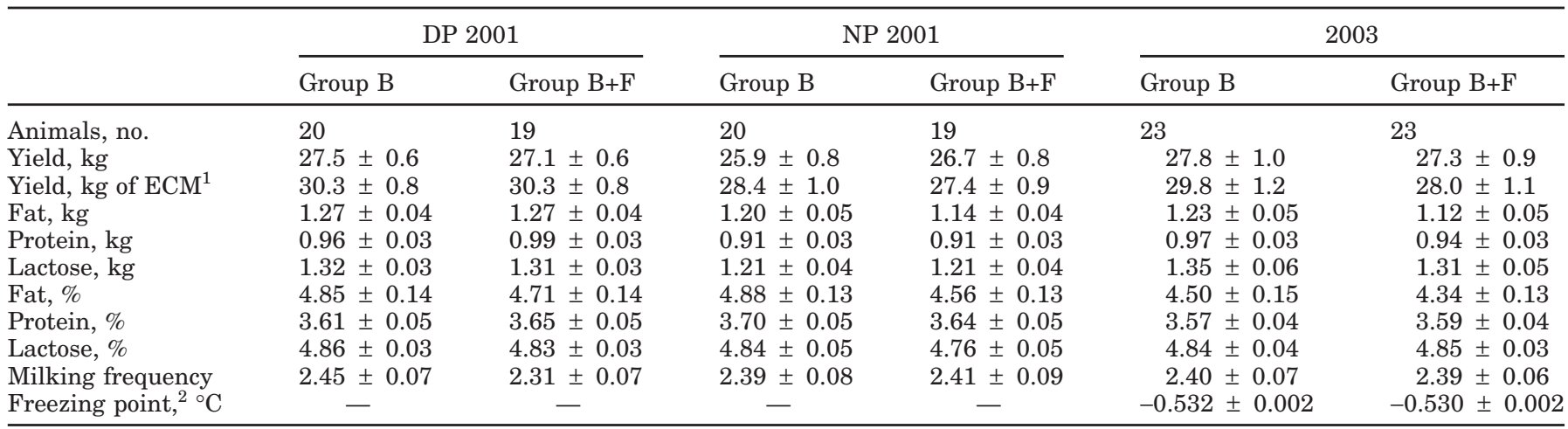

${ }^{1} \mathrm{ECM}=$ Energy-corrected milk.

${ }^{2}$ Freezing point was only determined during 2003.

only conventional means with ranges are presented in the results and no further statistical analysis was performed. The means presented are based on data from cows that were fetched because they had not voluntarily visited the milking unit during the last 12 to $14 \mathrm{~h}$. All other reasons for fetching cows (i.e., technical failure of the robot) were excluded from the analysis of fetched animals.

Analysis of water intake was performed for each of the 48-h registration periods. Water intake at water bowls was analyzed with the following model using the same symbols as in the models presented above:

$$
\mathrm{Y}_{\mathrm{ij}}=\mu+\alpha_{\mathrm{i}}+\gamma_{\mathrm{j}}+\beta_{2} \mathrm{X}_{\mathrm{ij}}+\mathrm{e}_{\mathrm{ij}}(2003)
$$

with water intake before the grazing season as a covariate in the model. Results are presented as least squares means with standard errors. Water intakes through intake of supplements and pasture are only presented as group means with standard errors.

Analysis of the distribution of the residuals was performed on the data from the behavior observations using the univariate procedure of SAS (SAS Institute, 1989). It was found that a normal distribution could be assumed for these variables and ANOVA was performed on the behavior observations using the following model:

$$
\mathrm{Yi}_{\mathrm{ln}}=\mu+\alpha_{\mathrm{i}}+\lambda_{1}+\mathrm{e}_{\mathrm{iln}}(2001 \text { and 2003) }
$$

where $\lambda_{l}$ is the fixed effect of the $l$ th parity $(1,2)$ and the other symbols are the same as presented above. Block, stage of lactation, and feed group and interactions were nonsignificant and therefore excluded from the model. Data on cow behavior are presented as least squares means with standard errors.

\section{RESULTS}

\section{Weather}

During the period of data registration in 2001, the average daily temperature was $16.5^{\circ} \mathrm{C}$, with $12 \mathrm{~d}$ when the maximum daily temperature was above $25^{\circ} \mathrm{C}$. Average rainfall was $1.6 \mathrm{~mm} / \mathrm{d}$, mainly distributed over 15 d with rainfall in excess of $1 \mathrm{~mm}$. In 2003, average daily temperature during the entire experiment was $15^{\circ} \mathrm{C}$, with maximum daily temperatures only surpassing $25^{\circ} \mathrm{C}$ on $2 \mathrm{~d}$ during the experiment. Average rainfall was $2.4 \mathrm{~mm} / \mathrm{d}$, mainly distributed during $9 \mathrm{~d}$ with rainfall events.

\section{Milk Production and Intake of Supplements}

Milk production and feed intake data from the 2 experiments are presented in Tables 2 and 3. No significant overall differences between treatments were found for any of the milk production, milk composition, or feed intake variables, except for a difference between treatments among the 10 cows in early lactation that received a silage supplement in 2003. Of these cows, a higher silage intake was observed among cows on treatment $\mathrm{B}$ compared with those on $\mathrm{B}+\mathrm{F}$ (Table 3).

An indication for treatment effects on milking frequency was obtained in 2001. During the last week on DP in 2001, the weather was warmer (high temperatures $>25^{\circ} \mathrm{C}$ ) and cows spent almost all day in the shade in the barn and went out to graze at night. When this week was excluded from the milking frequency data of the DP period, average milking frequency was higher $(P<0.05)$ for cows in group B compared with those in group $\mathrm{B}+\mathrm{F}$, having 2.4 and 2.2 milkings/d, respectively. However, when the data for the entire period on DP were analyzed, the difference in milking frequency be- 
Table 3. Intake of supplements of cows with drinking water in the barn (group B) or in the barn and in the field (group $\mathrm{B}+\mathrm{F}$ ) when grazing pasture areas distant (DP, $330 \mathrm{~m}$ from barn) and near (NP, $50 \mathrm{~m}$ from barn), in experiments conducted in 2001 and 2003 (least squares means $\pm \mathrm{SE}$ ).

\begin{tabular}{|c|c|c|c|c|c|c|}
\hline & \multicolumn{2}{|c|}{ DP 2001} & \multicolumn{2}{|c|}{ NP 2001} & \multicolumn{2}{|c|}{2003} \\
\hline & Group B & Group B+F & Group B & Group B+F & Group B & Group B+F \\
\hline & 20 & 19 & 20 & 19 & $23^{1}$ & $23^{1}$ \\
\hline Silage, kg of $\mathrm{DM}^{1}$ & $2.2 \pm 0.1$ & $2.2 \pm 0.1$ & $1.9 \pm 0.1$ & $1.8 \pm 0.1$ & $7.0 \pm 0.3^{\mathrm{a}}$ & $6.1 \pm 0.3^{\mathrm{b}}$ \\
\hline Hay, $\mathrm{kg}$ of DM & $1.5 \pm 0.1$ & $1.5 \pm 0.1$ & $1.5 \pm 0.1$ & $1.6 \pm 0.1$ & $1.1 \pm 0.1$ & $1.1 \pm 0.1$ \\
\hline Conc., kg of DM & $8.3 \pm 0.3$ & $8.2 \pm 0.4$ & $7.9 \pm 0.3$ & $8.3 \pm 0.3$ & $7.0 \pm 0.3$ & $6.9 \pm 0.2$ \\
\hline Supplements, MJ/cow per d & $151 \pm 5$ & $149 \pm 5$ & $141 \pm 5$ & $148 \pm 5$ & $142 \pm 5$ & $139 \pm 4$ \\
\hline
\end{tabular}

${ }^{\mathrm{a}, \mathrm{b}}$ Means within year and row with differing superscripts are significantly different $(P<0.05)$.

${ }^{1}$ Silage intake data in 2003 for 10 cows (<140 DIM). The remaining 36 cows (>140 DIM) received no silage.

tween groups was small and nonsignificant (Table 2). No significant difference between treatments in milking frequency was found in 2003.

The chemical compositions of supplementary feed and pasture herbage are presented in Table 4 . Nutrient contents of the pasture for the 2 treatment groups were comparable during both experimental years. In 2003, herbage DM was $20 \%$ and herbage mass was estimated at $1.6 \mathrm{ton} / \mathrm{ha}$ using a regression between sward height and herbage mass established on the same pasture area. No differences in DM or herbage mass were observed between treatments.

The average number of cows that were late for milking and therefore needed to be brought to the milking unit in the morning and afternoon is presented in Table 5 , together with information on where the cows were when they were fetched (barn or field). In the mornings, animals that needed to be fetched were often in the barn resting in the cubicles, whereas in the afternoon, animals often needed to be fetched from the field.

There was a large variation among animals; in 2001, 5 animals accounted for more than $50 \%$ of the times that cows were fetched. During 2003, 3 animals accounted for $50 \%$ of the times fetched, and 1 cow accounted for $26 \%$ of the total. As mentioned previously, no statistical analysis was performed to study differences between treatments due to the large variation among animals.

\section{Water Intake}

No significant difference was found between treatments when data for the different subperiods (transition, DP, and NP periods) were analyzed separately.

Table 4. Chemical composition and nutrient content (means and SD) of pasture and supplements fed in the barn in 2001 and 2003 for treatment groups B (water available in barn only) and B+F (water available in barn and in field).

\begin{tabular}{|c|c|c|c|c|}
\hline & $\begin{array}{l}\text { Ash, } \\
\% \text { of } \mathrm{DM}\end{array}$ & $\begin{array}{l}\mathrm{CP}, \\
\% \text { of } \mathrm{DM}\end{array}$ & $\begin{array}{l}\mathrm{NDF}, \\
\% \text { of DM }\end{array}$ & $\begin{array}{l}\mathrm{ME},{ }^{1} \\
\mathrm{MJ} / \mathrm{kg} \text { of } \mathrm{DM}\end{array}$ \\
\hline \multicolumn{5}{|l|}{2001} \\
\hline Distant pasture, group B & $8.9(0.6)$ & $13.6(2.9)$ & $44.5(1.6)$ & $10.8(0.4)$ \\
\hline Distant pasture, group $\mathrm{B}+\mathrm{F}$ & $10.0(0.4)$ & $13.7(2.4)$ & $42.9(5.2)$ & $10.8(0.5)$ \\
\hline Near pasture, group B & $10.0(0.4)$ & $15.7(0.4)$ & $42.9(4.1)$ & $10.0(0.1)$ \\
\hline Near pasture, group $\mathrm{B}+\mathrm{F}$ & $9.8(1.3)$ & $17.7(0.6)$ & $45.9(0.3)$ & $10.3(0.2)$ \\
\hline Grass silage $^{2}$ & $8.6(1.3)$ & $15.7(0.9)$ & $49.2(1.3)$ & $10.7(0.2)$ \\
\hline Hay & $6.0(0.9)$ & $8.7(3.0)$ & $53.9(5.6)$ & $10.4(0.0)$ \\
\hline Concentrate $^{3}$ & 4.9 & 22.0 & $\mathrm{NA}^{4}$ & 13.4 \\
\hline \multicolumn{5}{|l|}{2003} \\
\hline Distant pasture, group B & $9.5(0.4)$ & $19.1(2.0)$ & $39.7(4.7)$ & $11.3(0.4)$ \\
\hline Distant pasture, group $\mathrm{B}+\mathrm{F}$ & $9.5(0.3)$ & $19.3(1.2)$ & $36.7(3.4)$ & $11.4(0.4)$ \\
\hline Grass silage $^{2}$ & $8.7(1.5)$ & $14.2(0.8)$ & $49.6(2.5)$ & $10.2(0.5)$ \\
\hline $\mathrm{Hay}^{3}$ & 6.8 & 13.3 & 52.3 & 11.0 \\
\hline Concentrate $^{3}$ & 4.9 & 19.2 & NA & 13.7 \\
\hline
\end{tabular}

${ }^{1} \mathrm{ME}=$ Metabolizable energy.

${ }^{2}$ Dry matter content of silage was 38 and $45 \%, \mathrm{NH}_{3}-\mathrm{N}$ was 67 and $61 \mathrm{~g} / \mathrm{kg}$ of total $\mathrm{N}$, whereas pH was 4.0 and 5.0 in 2001 and 2003, respectively.

${ }^{3}$ Daily sampling pooled together. No standard deviation (single analysis).

${ }^{4} \mathrm{NA}=$ Not analyzed. 
Table 5. Number of cows with access to drinking water only in the barn (B) or drinking water in the barn and in the field $(\mathrm{B}+\mathrm{F})$ that had not entered the milking unit for more than $12 \mathrm{~h}$ and that needed to be fetched manually in the morning and in the afternoon. Averages presented with ranges in parenthesis. The distant pasture was $330 \mathrm{~m}$ from barn and the near pasture was $50 \mathrm{~m}$ from barn.

\begin{tabular}{|c|c|c|c|c|c|c|}
\hline \multirow[b]{2}{*}{ Year } & \multirow{2}{*}{$\begin{array}{l}\text { Treatment } \\
\text { group }\end{array}$} & \multicolumn{2}{|c|}{ Morning } & \multicolumn{2}{|c|}{ Afternoon } & \multirow[b]{2}{*}{ Total } \\
\hline & & $\operatorname{Barn}^{1}$ & Field $^{1}$ & Barn & Field & \\
\hline 2001 Distant pasture & $\begin{array}{l}\mathrm{B} \\
\mathrm{B}+\mathrm{F}\end{array}$ & $\begin{array}{ll}2.2 & (0-5) \\
1.5 & (0-4)\end{array}$ & $\begin{array}{l}0(0-0) \\
0(0-0)\end{array}$ & $\begin{array}{ll}0.2 & (0-1) \\
0.5 & (0-2)\end{array}$ & $\begin{array}{ll}0.3 & (0-2) \\
0.6 & (0-4)\end{array}$ & $\begin{array}{l}2.7 \\
2.6\end{array}$ \\
\hline 2001 Near pasture & $\begin{array}{l}\mathrm{B} \\
\mathrm{B}+\mathrm{F}\end{array}$ & $\begin{array}{ll}2.9 & (1-5) \\
0.7 & (0-2)\end{array}$ & $\begin{array}{l}0.1(0-1) \\
0.2(0-2)\end{array}$ & $\begin{array}{ll}0.5 & (0-2) \\
0.3 & (0-1)\end{array}$ & $\begin{array}{l}0.1(0-1) \\
1.4(0-5)\end{array}$ & $\begin{array}{l}3.6 \\
2.6\end{array}$ \\
\hline 2003 Distant pasture & $\begin{array}{l}\mathrm{B} \\
\mathrm{B}+\mathrm{F}\end{array}$ & $\begin{array}{ll}0.4 & (0-1) \\
1.3 & (0-4)\end{array}$ & $\begin{array}{l}0(0-0) \\
0(0-0)\end{array}$ & $\begin{array}{ll}0.2 & (0-2) \\
0.2 & (0-2)\end{array}$ & $\begin{array}{ll}0.2 & (0-1) \\
0.7 & (0-3)\end{array}$ & $\begin{array}{l}0.8 \\
2.2\end{array}$ \\
\hline 2003 Near pasture & $\begin{array}{l}\mathrm{B} \\
\mathrm{B}+\mathrm{F}\end{array}$ & $\begin{array}{l}0.9(0-3) \\
0.9(0-2)\end{array}$ & $\begin{array}{l}1.4(0-3) \\
1.6(0-3)\end{array}$ & $\begin{array}{l}0.3(0-1) \\
0(0-0)\end{array}$ & $\begin{array}{l}0.6(0-2) \\
1.7(0-2)\end{array}$ & $\begin{array}{l}3.2 \\
4.2\end{array}$ \\
\hline
\end{tabular}

${ }^{1}$ Barn $=$ fetched from the barn; field $=$ fetched from the field.

Intake of drinking water during the different subperiods was similar, around $50 \mathrm{~L} /$ cow per $\mathrm{d}$. Therefore, least squares means for the whole experimental period (DP $+\mathrm{NP})$ are presented in Table 6 , together with data on daily water intake from feed and water bowls. No significant difference in intake of drinking water was observed between cows on treatment $\mathrm{B}+\mathrm{F}$ compared with cows on treatment $B$. Animals with access to drinking water in the field consumed a large proportion of their total drinking water in the field as follows: during the transition period (28\%); during the period on DP (55\%); and on NP (67\%). There was a large variation in water intake among animals with an average intake during the main experiment of $52 \mathrm{~L}$, with a standard deviation of 14 and range of 24 to $79 \mathrm{~L} / \mathrm{d}$. The variation was only slightly higher than during the indoor period. The average water intake during the indoor covariate period was $66 \mathrm{~L}$ (SD 13; range 44 to $90 \mathrm{~L} / \mathrm{d}$ ). The correlation between water intake during the indoor covariate period and the pasture period was 0.67 .

When analyzing water intake during the first $30 \mathrm{~min}$ after each time a cow entered the barn, cows in groups
$\mathrm{B}$ and $\mathrm{B}+\mathrm{F}$ drank 21.7 and $4.8 \mathrm{~L}$, respectively $(P \leq$ 0.001 ). For group $B$, the water consumed in the first 30 min after entering the barn corresponds to approximately $40 \%$ of their total water intake. The analysis of water intake during the period 30 to $60 \mathrm{~min}$ after entering the barn showed that during the second $30 \mathrm{~min}$ after entrance, least squares means for water intake in groups $\mathrm{B}$ and $\mathrm{B}+\mathrm{F}$ was only 3.4 and $1.1 \mathrm{~L}$, respectively $(P \leq 0.001)$.

Average daily temperature during the $6 \mathrm{~d}$ of water intake registrations was $15.2^{\circ} \mathrm{C}$, with a range of 11.6 to $17.7^{\circ} \mathrm{C}$. Maximum daily temperature ranged between 17.9 and $23.4^{\circ} \mathrm{C}$. Almost no rainfall occurred but on the last observation day there was $0.8 \mathrm{~mm}$ of rain.

\section{Animal Behavior}

Behavior observations from 2001 of animals grazing on $\mathrm{DP}$ showed that cows in treatment group $\mathrm{B}+\mathrm{F}$ spent more time on pasture and grazed longer than animals in group B (Table 7). Behavior observations performed during the transition period in 2003 also showed that

Table 6. Daily water intake during the 2003 experiment from water bowls (least squares means \pm SE) and through feed consumption (means $\pm \mathrm{SD}$ ) of cows with drinking water in the barn (group B) or in the barn and the field (group $\mathrm{B}+\mathrm{F}$ ). No significant differences $(P>0.05)$ between treatments were found for any of the variables studied below.

\begin{tabular}{lllr}
\hline & Registration & \multicolumn{2}{c}{ Water intake, L/cow per d } \\
\cline { 3 - 4 } Water source & period & $52.5 \pm 1.8$ & Group B+F \\
\hline${\text { Intake from water bowls, }{ }^{1} \mathrm{~L}}^{144^{1} \mathrm{~h}}$ & $2.2(3.3)$ & $51.2 \pm 1.7$ \\
Intake from supplements, $\mathrm{L}_{\text {Estimated intake from pasture, }{ }^{2} \mathrm{~L}}^{29 \mathrm{~d}}$ & $29 \mathrm{~d}$ & $37.9(13.8)$ & $2.7(3.3)$ \\
Total water intake, L & & 92.6 & $35.2(15.2)$ \\
\hline
\end{tabular}

\footnotetext{
${ }^{1}$ Registrations of water intake on pasture and in barn were synchronized in time and performed during three 48-h periods [two 48-h periods for the distant (330 $\mathrm{m}$ from barn) and one 48 -h period for the near (50 $\mathrm{m}$ from barn) pasture].

${ }^{2}$ Estimating pasture intake by assuming a total roughage intake (silage + hay + pasture herbage) of 10 to $12 \mathrm{~kg}$ of DM.
} 
Table 7. Behavior of cows with drinking water in the barn (group B) or in the barn and in the field (group $\mathrm{B}+\mathrm{F}$ ) when grazing pasture areas distant (DP, $330 \mathrm{~m}$ from barn) and near (NP, $50 \mathrm{~m}$ from barn), in experiments conducted in 2001 and 2003, and during the transition period in 2003 (least squares means \pm $\mathrm{SE})$.

\begin{tabular}{|c|c|c|c|c|}
\hline & \multicolumn{2}{|c|}{2001} & \multicolumn{2}{|c|}{2003} \\
\hline & Group B & Group B+F & Group B & Group B+F \\
\hline \multicolumn{5}{|l|}{ Transition period } \\
\hline Animals, no. & - & - & 11 & 11 \\
\hline Time on pasture, $\%$ & - & - & $19.4 \pm 2.4^{\mathrm{a}}$ & $28.6 \pm 2.1^{b}$ \\
\hline Time grazing, \% & - & - & $15.6 \pm 1.8^{\mathrm{a}}$ & $21.0 \pm 1.6^{\mathrm{b}}$ \\
\hline Time lying on pasture, $\%$ & - & - & $3.1 \pm 1.0^{\mathrm{a}}$ & $6.2 \pm 0.9^{b}$ \\
\hline \multicolumn{5}{|l|}{ Distant pasture } \\
\hline Animals, no. & 10 & 10 & 11 & 11 \\
\hline Time on pasture, $\%$ & $34.1 \pm 1.9^{\mathrm{a}}$ & $40.0 \pm 2.0^{\mathrm{b}}$ & $41.2 \pm 1.9$ & $43.0 \pm 1.7$ \\
\hline Time grazing, $\%$ & $16.8 \pm 1.2^{\mathrm{a}}$ & $20.6 \pm 1.2^{\mathrm{b}}$ & $27.2 \pm 1.2$ & $26.0 \pm 1.1$ \\
\hline Time lying on pasture, $\%$ & $8.0 \pm 1.0$ & $10.3 \pm 1.0$ & $11.2 \pm 1.8$ & $13.3 \pm 1.6$ \\
\hline \multicolumn{5}{|l|}{ Near pasture } \\
\hline Animals, no. & $9^{1}$ & 10 & 11 & 11 \\
\hline Time on pasture, $\%$ & $47.6 \pm 3.7$ & $53.5 \pm 3.6$ & $63.9 \pm 4.7$ & $67.9 \pm 4.3$ \\
\hline Time grazing, \% & $18.5 \pm 1.9$ & $22.6 \pm 1.9$ & $26.8 \pm 1.8$ & $28.1 \pm 1.6$ \\
\hline Time lying on pasture, \% & $18.0 \pm 2.0$ & $20.0 \pm 2.0$ & $34.3 \pm 3.7$ & $32.0 \pm 3.4$ \\
\hline
\end{tabular}

${ }^{\mathrm{a}, \mathrm{b}}$ Means within year and row with differing superscripts are significantly different $(P<0.05)$.

${ }^{1}$ One cow was removed from the experiment due to a hoof infection.

cows in group $\mathrm{B}+\mathrm{F}$ spent a significantly higher percentage of their time in the field, mainly grazing and lying down, compared with group B.

An effect of parity was observed, where cows in their second or higher lactation were found to spend more time out on the pasture compared with cows in their first lactation. The difference between the age groups in time spent on pasture, time grazing, and time lying down was significant on the distant pasture in 2001, whereas a tendency $(P=0.06)$ was seen for a difference between older and younger cows in time spent lying on pasture when animals grazed on NP in 2003 (Table 8). In contrast, behavior observations in the transition period of 2003 showed that younger animals spent more of their time in the field at the beginning of the grazing season and spent more of their time grazing compared with older animals.

A difference in behavior when cows were on NP compared with DP was observed in both experiments. Cows spent more of their time in the pasture area, mainly lying down in the field when they had access to NP (Table 7). In most cases, a slight increase in time spent grazing was found when animals moved from DP to NP.

\section{DISCUSSION}

In the present experiment, water supply for cows in treatment group B was not restricted in a formal sense, as cows could always walk back to the barn to drink. However, it has been shown in earlier experiments (Spörndly and Wredle, 2004) that cows in automatic milking systems may be reluctant to walk distances as short as $260 \mathrm{~m}$ and that a long distance between barn and pasture may have negative effects on milk production. The reluctance of cows to walk longer distances to drink water has been reported (Phillips, 1993), and longer distance to drinking water can be interpreted as, in a sense, a restriction on voluntary water intake. The results of this experiment, however, showed no difference in water intake between treatments at similar walking distances as reported in the experiments mentioned above (Phillips, 1993; Spörndly and Wredle, 2004). Therefore, it is not surprising that there were no differences in milk yield or milk composition between the treatment groups. These results agree with the findings reported by Little et al. (1976), where water intake was restricted for a period of $6 \mathrm{~d}$, and a second report (Little et al., 1978) of water restriction during a 3 -wk period. In both experiments, milk yield was lowered by limiting water supply but was unaffected during the first 24-h period of water restriction. In the present experiment, restrictions on water availability lasted less than $24 \mathrm{~h}$ and no difference in water intake on a 24-h basis was observed. Thus, the results of several experiments indicate that short-term restrictions in water availability $(\leq 24 \mathrm{~h})$ do not lower milk yield. The lack of difference in water intake between the 2 groups in the present experiment showed that cows without access to drinking water for a few hours compensated by drinking more when water was available, and reached the same level of daily water intake as cows with 24-h access. The high water intake of group B during the first $30 \mathrm{~min}$ after entering the barn indicated that they were thirsty and that thirst may have been 
Table 8. Behavior of cows in first lactation compared with older cows when grazing distant (330 m from barn) and near (50 m from barn) pasture areas, in experiments conducted in 2001 and 2003 (least squares means $\pm \mathrm{SE})$.

\begin{tabular}{|c|c|c|c|c|}
\hline & \multicolumn{2}{|c|}{2001} & \multicolumn{2}{|c|}{2003} \\
\hline & First calvers & Older cows & First calvers & Older cows \\
\hline \multicolumn{5}{|l|}{ Transition period } \\
\hline Animals, no. & - & - & 6 & 16 \\
\hline Time on pasture, $\%$ & - & - & $28.1 \pm 2.9^{\mathrm{a}}$ & $19.9 \pm 1.8^{\mathrm{b}}$ \\
\hline Time grazing, \% & - & - & $21.3 \pm 2.1^{\mathrm{a}}$ & $15.2 \pm 1.3^{\mathrm{b}}$ \\
\hline Time lying on pasture, \% & - & - & $5.4 \pm 1.2$ & $3.9 \pm 0.7$ \\
\hline \multicolumn{5}{|l|}{ Distant pasture } \\
\hline Animals, no. & 7 & 10 & 6 & 16 \\
\hline Time on pasture, $\%$ & $32.6 \pm 2.3^{a}$ & $41.5 \pm 1.7^{\mathrm{b}}$ & $43.7 \pm 2.3$ & $40.6 \pm 1.4$ \\
\hline Time grazing, \% & $16.6 \pm 1.4^{\mathrm{a}}$ & $20.7 \pm 1.0^{\mathrm{b}}$ & $28.1 \pm 1.5$ & $25.1 \pm 0.9$ \\
\hline Time lying on pasture, $\%$ & $7.6 \pm 1.1^{\mathrm{a}}$ & $10.7 \pm 0.8^{b}$ & $12.5 \pm 2.2$ & $12.1 \pm 1.3$ \\
\hline \multicolumn{5}{|l|}{ Near pasture } \\
\hline Animals, no. & 7 & 12 & 6 & 16 \\
\hline Time on pasture, \% & $46.0 \pm 4.2$ & $55.1 \pm 3.2$ & $60.3 \pm 5.8$ & $71.5 \pm 3.5$ \\
\hline Time grazing, $\%$ & $18.7 \pm 2.1$ & $22.3 \pm 1.6$ & $27.6 \pm 2.1$ & $27.2 \pm 1.3$ \\
\hline Time lying on pasture, \% & $16.7 \pm 2.3$ & $21.3 \pm 1.7$ & $27.8 \pm 4.5$ & $38.5 \pm 2.7$ \\
\hline
\end{tabular}

${ }^{\mathrm{a}, \mathrm{b}}$ Means within year and row with differing superscripts are significantly different $(P<0.05)$.

an important reason for returning to the barn. However, the lack of significant differences between the treatment groups in time spent on pasture and in milking frequency in 2003 shows that the animals with access to water in the field also returned to the barn regularly.

The results of the present experiment showed that after the transition period, cows with access to drinking water in the field (group $\mathrm{B}+\mathrm{F}$ ) consumed more than $50 \%$ of their drinking water in the field. The proportion of water consumed in the field seemed to increase as the season progressed, from $28 \%$ during the transition period to $55 \%$ on DP and $67 \%$ on NP. However, a slow adaptation to the new circumstances of water supply after pasture let-out could be the reason for the low figure during the transition period. The lower proportion of water intake on DP compared with NP can be explained by the large increase in time spent on pasture when moving from DP to NP, an increase from 43 to $67.9 \%$ corresponding to $6 \mathrm{~h} / \mathrm{d}$. In data from $2001 \mathrm{using}$ drinking time as an indirect measure of water intake (unpublished), time spent drinking in the field varied but did not increase as the season progressed, which indicates that the explanations given above may be relevant. The overall high proportion of water consumed in the field does, however, indicate that cows were often thirsty and liked to drink while grazing, even though pasture herbage is a feed with high water content. An experiment performed during the indoor season (Nocek and Braund, 1985) gave similar results and showed that cows often drank in connection with feeding, preferring to alternate between eating and drinking when given the option. With the increased concern for animal welfare, the large proportion of water consumed in the field in this experiment is a strong argument for having a water supply both in the field and in the barn during the pasture season, even though the need for water in the field for production reasons seems doubtful in temperate climates and has been questioned on the basis of earlier experimental results (Castle, 1972; Castle and Watson, 1973).

A slightly lower milking frequency was observed for cows in group $\mathrm{B}+\mathrm{F}$ compared with cows in group $\mathrm{B}$ during part of the period on DP in the 2001 experiment. During the experiment, however, the difference between treatments was not significant $(P>0.05)$ for the whole period on DP and no such effect was found in 2003 (Table 2). Therefore, it must be concluded that the effects on milking frequency of offering water in the field are negligible at the distances between barn and pasture used in these experiments. The slightly lower milking frequency in group $\mathrm{B}+\mathrm{F}$ observed during part of the DP period in 2001 did, however, indicate that the effect on milking frequency might be larger at longer distances between barn and pasture than the distances in these experiments.

The average intake of drinking water in the 2003 experiment was comparatively low, only 51.2 to $52.5 \mathrm{~L} /$ $\mathrm{d}$. This is somewhat lower than the estimated water intake of $57 \mathrm{~L} / \mathrm{d}$ obtained using the regression presented by Dahlborn et al. (1998) at a production level of $27 \mathrm{~L}$ of milk and 30\% DM content of the total feed supply (pasture and supplements). Their findings, however, were based on data from an indoor period with a much higher DM content in feed (range 46 to $88 \%$ ) than in pasture and is therefore not directly applicable to pas- 
ture situations. Stockdale and King (1983) studied water intake of dairy cows at pasture and found that the total water intake could be estimated fairly well but that it was more difficult to predict the daily intake of drinking water due to the large day-to-day effects of rainfall and other climatic conditions (temperature, humidity, wind, sunshine, and evaporation).

The estimated total water intake of approximately $90 \mathrm{~L}$ per animal in this experiment was comparable to research results reported by NRC (2001), where the total water intake of dairy cows was estimated to be 2.6 to $3.0 \mathrm{~L}$ per liter of milk produced for cows producing 33 to $35 \mathrm{~L} / \mathrm{d}$, and 3.3 to $4.2 \mathrm{~L}$ of water per liter of milk for cows producing $<26 \mathrm{~L} / \mathrm{d}$. The total water intake for animals in this experiment was approximately $3.3 \mathrm{~L}$ per liter of milk, which is within the range reported by NRC (2001). Using the regression of Stockdale and King (1983) for predicting total water intake under grazing conditions, a total water intake of $96 \mathrm{~L}$ is obtained, assuming a total DMI of $18 \mathrm{~kg}$ with a $30 \% \mathrm{DM}$ content of feed and a mean temperature of $15^{\circ} \mathrm{C}$, which is similar to the estimate obtained in Table 6. Stockdale and King (1983) based their regression on data from cows in early lactation, whereas in the present experiment, most animals were in the latter part of lactation. Thus, the slightly higher regression value reported by Stockdale and King (1983) seems reasonable.

A high variation among individual cows in drinking water intake was observed and has been reported elsewhere (Commonwealth Agricultural Bureau, 1980; Dado and Allen, 1994). However, the pretrial covariate period was effective in reducing the effects of variation among animals.

The results of the behavior study in 2001 showed that cows with access to drinking water in the field spent significantly more time on pasture and more time grazing than cows that had drinking water only in the barn $(P<0.05$; Table 7$)$. This indicates that animals in group B left the field earlier because they were thirsty. However, this had no effect on milk production and in 2003, similar effects of treatment on behavior were observed only during the transition period.

In the experiments reported here, cows in the 2 treatment groups grazed simultaneously at the same distances to ensure comparable grazing conditions between treatments. A statistical analysis of the effect of distance on animal behavior was not performed, as it was not possible to separate the effects of distance from the effect of period. However, it is interesting to note that similar values for time spent on the distant and near pastures were obtained in an earlier experiment by Spörndly and Wredle (2004), where cows spent significantly more time out on the pasture when they grazed on NP compared with DP. The longer time in the field when grazing NP was mainly spent lying down. Other behavior studies performed during the grazing season have shown that when given a choice, cows prefer lying on pasture to lying indoors (Krohn et al., 1992; Ketelaar-de Lauwere et al., 1999). In view of this, the difference indicates that the cows preferred the NP area.

Although the 2 treatment groups grazed in separate paddocks with separate cow access lanes, the fields were adjacent and it is possible that there was a certain degree of synchronization between the 2 groups, especially when they happened to be grazing near the fence close to each other. This is something that has to be taken into consideration when viewing the results of this experiment.

The practice on many AMS farms of offering drinking water only in the barn was introduced with the objective of increasing the cow's motivation to return to the barn and thereby maintain a high milking frequency during the pasture season. The results from these 2 experiments have shown that this objective was not achieved. Although no negative effect of the practice was observed on milk yield, these experiments have shown no reason for not offering drinking water in pasture as well as in the barn during the grazing season.

\section{CONCLUSIONS}

With walking distances up to $\sim 300 \mathrm{~m}$, there seems to be no difference in milk production or milking frequency between cows with drinking water in the barn only, and those with drinking water in the field and in the barn in an automatic milking system. However, after the transition period, the cows with drinking water in the field consumed more than $50 \%$ of their drinking water out on pasture, indicating that the animals became thirsty and wanted to drink during the time they spent in the field. Behavior observations indicated that cows with water in the field spent more time outdoors and more time grazing than cows that had to go to the barn to drink. However, these differences in behavior between treatments were only significant during 1 period in 1 of $2 \mathrm{yr}$ of the experiment. As no advantages of limiting water supply to the barn were found, a supply of drinking water in the field is recommended for animal welfare reasons and to ensure ample water supply in all situations.

\section{ACKNOWLEDGMENTS}

Maria Bergman, Cecilia Karlsson, and Ann-Charlotte Englund made valuable contributions to data collection. These experiments were financed by the Swedish Farmer's Foundation for Agricultural Research and 
the European Union. These contributions are gratefully acknowledged.

\section{REFERENCES}

Åkerlind, M., K. Holtenius, J. Bertilsson, and M. Emanuelson. 1999. Milk composition and feed intake in dairy cows selected for high or low milk fat percentage. Livest. Prod. Sci. 59:1-11.

Castle, M. E. 1972. A study of the intake of drinking water by dairy cows at grass. J. Br. Grassl. Soc. 27:207-210.

Castle, M. E., and J. N. Watson. 1973. The intake of drinking water by grazing dairy cows. The effect of water availability. J. Br. Grassl. Soc. 28:203-207.

Commonwealth Agricultural Bureau. 1980. The Nutrient Requirements of Ruminant Livestock. Commonwealth Agricultural Bureau, Gresham Press, Woking, UK.

Dado, R. G., and M. S. Allen. 1994. Variation in and relationships among feeding, chewing and drinking variables for lactating dairy cows. J. Dairy Sci. 77:132-144.

Dahlborn, K., M. Åkerlind, and G. Gustafson. 1998. Water intake by dairy cows selected for high or low milk-fat percentage when fed two forage to concentrate ratios with hay or silage. Swed. J. Agric. Res. 28:167-176.

Goering, H. K., and P. J. Van Soest. 1970. Forage Fiber Analyses (Apparatus, Reagents, Procedures and Some Applications). Agric. Handbook No. 379. ARS-USDA, Washington, DC.

Ketelaar-de Lauwere, C. C., A. H. Ipema, E. N. J. van Ouwerkerk, M. M. W. B. Hendriks, J. H. M. Metz, J. P. T. M. Noordhuizen, and W. G. P. Schouten. 1999. Voluntary automatic milking in combination with grazing dairy cows. Milking frequency and effects on behaviour. Appl. Anim. Behav. Sci. 64:91-109.

Krohn, C. C., and L. Munksgaard. 2004. Results of Partner 3 in: Automatic milking and grazing. Grazing strategies and their effect on animal welfare and system performance Deliverable D27 (C. C. Krohn, ed.) EU project "Implications of the introduction of automatic milking on dairy farms" (QLK5-2000-31006). Online. Available http://www.automaticmilking.nl. Accessed Aug. 19, 2004.

Krohn, C. C., L. Munksgaard, and B. Jonasen. 1992. Behaviour of dairy cows kept in extensive (loose housing/pasture) or intensive (tie stall) environments. I. Experimental procedure, facilities, time budgets-diurnal and seasonal conditions. Appl. Anim. Behav. Sci. 34:37-47.

Lindgren, E. 1979. Nutrient content in roughages determined in vitro and with different laboratory methods. Report 45, Dept. Anim.
Nutr. Management, Swedish Univ. Agric. Sci., Uppsala, Sweden. (In Swedish)

Little, W., B. F. Sansom, R. Manston, and W. M. Allen. 1976. Effects of restricting the water intake of dairy cows upon their milk yield, body weight and blood composition. Anim. Prod. 22:329-339.

Little, W., B. F. Sansom, R. Manston, and W. M. Allen. 1978. The effects of reducing the water intake of lactating dairy cows by $40 \%$ for 3 weeks. Anim. Prod. 27:79-87.

Murphy, M. R. 1992. Water metabolism of dairy cattle. J. Dairy Sci. 75:326-333.

Nocek, J. E., and D. G. Braund. 1985. Effect of feeding frequency on diurnal dry matter and water consumption, liquid dilution rate, and milk yield in first lactation. J. Dairy Sci. 68:2238-2247.

NRC. 2001. Page 20 in Nutrient Requirements of Dairy Cattle. 7th rev. ed. Natl. Acad. Sci., Washington, DC.

Olsson, G., M. Emanuelson, and H. Wiktorsson. 1997. Effects on milk production and health of dairy cows by feeding different rations of concentrate/forage and additional fat before calving. Acta Agric. Scand. A Anim. Sci. 47:91-105.

Phillips, C. J. C. 1993. Cattle Behaviour. Farming Press, Ipswich, UK

SAS Institute. 1989. SAS User's Guide: Statistics. Version 6.12 ed. SAS Inst., Inc., Cary, NC.

Sjaunja, L.-O., L. Baevre, L. Junkkarinen, J. Pedersen, and J. Setälä. 1991. A Nordic proposal for an energy corrected milk (ECM) formula. Pages 156-157 in Proc. 27th Biennial Session of the International Committee for Animal Recording, Paris, France. EAAP, Rome, Italy.

Spörndly, E., and E. Burstedt. 1996. Effects of sward height and season on herbage intake of strip-grazed dairy cows. Acta Agric. Scand. A Anim. Sci. 46:87-96.

Spörndly, E., and E. Wredle. 2002. Automatic milking and grazingMotivation to visit the milking robot. Deliverable D26, EU project "Implications of the introduction of automatic milking on dairy farms" (QLK5-2000-31006). Online. Available http://www.automaticmilking.nl. Accessed Aug. 19, 2004.

Spörndly, E., and E. Wredle. 2004. Automatic milking and grazingEffects of distance to pasture and level of supplements on milk yield and cow behavior. J. Dairy Sci. 87:1702-1712.

Stockdale, C. R., and K. R. King. 1983. A note on some of the factors that affect the water consumption of lactating dairy cows at pasture. Anim. Prod. 36:303-306.

van Dooren, H. J. C., E. Spörndly, and H. Wiktorsson. 2002. Automatic milking and grazing. Applied grazing strategies. Deliverable D25, EU project "Implications of the introduction of automatic milking on dairy farms" (QLK5-2000-31006). Online. Available http:// www.automaticmilking.nl. Accessed Aug. 19, 2004. 